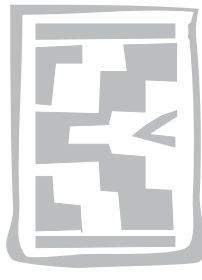

\title{
Preliminary survey of ticks (Acari: Ixodidae) on cattle in Central Equatoria State, Southern Sudan
}

\author{
D.A. SALIH ${ }^{1 *}$, I.I. JULLA ${ }^{2}$, S.M. HASSAN ${ }^{3}$, A.M. EL HUSSEIN ${ }^{1}$ and F. JONGEJAN ${ }^{4,5}$
}

\begin{abstract}
SALIH, D.A., JULLA, I.I., HASSAN, S.M., EL HUSSEIN, A.M. \& JONGEJAN, F. 2008. Preliminary survey of ticks (Acari: Ixodidae) on cattle in Central Equatoria State, Southern Sudan. Onderstepoort Journal of Veterinary Research, 75:47-53

In a preliminary survey conducted in 2005 , the species composition and seasonality of ticks infesting cattle in Central Equatoria State, Southern Sudan was determined. Three locations were selected (Gumbo, Khor Rumla and Nyaing) and surveyed every 3 months. Two cattle herds in each of the three locations were visited four times during the study period. Total body collections of ticks were made from each of five cattle (Nilotic Zebu breed) kept in six different herds. Four tick genera and ten species were identified. The tick species identified were Amblyomma lepidum, Amblyomma variegatum, Boophilus annulatus, Boophilus decoloratus, Hyalomma marginatum rufipes, Hyalomma truncatum, Rhipicephalus appendiculatus, Rhipicephalus evertsi evertsi, Rhipicephalus praetextatus and Rhipicephalus sanguineus group. The highest number of ticks was collected in October during the rainy season. A finding of great significance was that $R$. appendiculatus, vector of East Coast fever, has now firmly established itself throughout the year with possible implications for cattle production in Central Equatoria State.
\end{abstract}

Keywords: Cattle, preliminary survey, Southern Sudan, ticks

\section{INTRODUCTION}

Southern Sudan is situated approximately between latitudes $4^{\circ} \mathrm{N}$ to $10^{\circ} \mathrm{N}$ and longitudes $24^{\circ} \mathrm{E}$ to $36^{\circ} \mathrm{E}$

* Author to whom correspondence is to be directed: E-mail: diaeldin2000@ hotmail.com

1 Central Veterinary Research Laboratories, Al Amarat, P.O. Box 8067, Khartoum, Sudan

2 College of Veterinary Science, University of Bahr El Ghazal, P.O. Box 10739, Khartoum, Sudan

3 Department of Parasitology, Faculty of Veterinary Medicine, University of Khartoum, P.O. Box 32, Khartoum North, Sudan

4 Utrecht Centre for Tick-borne Diseases, Department of Infectious Diseases and Immunology, Faculty of Veterinary Medicine, Utrecht University, Yalelaan 1, 3584 CL Utrecht, The Netherlands

5 Department of Veterinary Tropical Diseases, Faculty of Veterinary Science, University of Pretoria, Onderstepoort, 0110 South Africa

Accepted for publication 28 September 2007-Editor and has an annual rainfall ranging between 900 and $1500 \mathrm{~mm}$. Livestock are mainly comprised of cattle, goats and sheep. The local people depend primarily on cattle to satisfy their needs for meat, milk and milk by-products, but sheep and goats are also a source of meat. The cattle population of Central Equatoria State is estimated to be 7.5 million and consists mainly of the local Nilotic Zebu breed.

Hoogstraal (1956) reported 49 species of ticks that infest both domestic and wildlife in Southern Sudan. The most important among these ticks is Rhipicephalus appendiculatus (the vector of East Coast fever caused by the protozoan parasite Theileria parva), which is mainly distributed in areas of high rainfall and moderate temperature, such as the district of Kajo Kaji, Yei, Ngangala, Torit and Katire. In addition, this tick was identified in Chukudum, Aswa River, Palotaka, Nimule and Juba (Morzaria, Tat- 
chell, Minor, Pederson, Julla, Rahim, Dyson \& Aarle 1981; Julla 1985, 1994). However, information regarding the prevalence of $R$. appendiculatus and other tick species infesting livestock in Southern Sudan and their economic impact is lacking. This is mainly due to the lack of adequate laboratory facilities and trained personnel to conduct research on ticks, in addition to long standing civil unrest. This study was initiated to update the current distribution of ticks infesting cattle in Central Equatoria State, Southern Sudan.

\section{MATERIALS AND METHODS}

\section{Study area}

The study was conducted over 12 months from January to December 2005 around the city of Juba $\left(4^{\circ} 50^{\prime} \mathrm{N} ; 31^{\circ} 35^{\prime} \mathrm{E}\right)$, the capital of Central Equatoria State, Southern Sudan (Fig. 1). The climate around Juba is (semi)equatorial, with minimal variations in seasonal temperatures. The highest mean maximum ambient temperature usually occurs during January in the dry season with a daily maximum ranging between $30^{\circ}$ and $32^{\circ} \mathrm{C}$. The mean minimum temperature occurs during the rainy season which is from

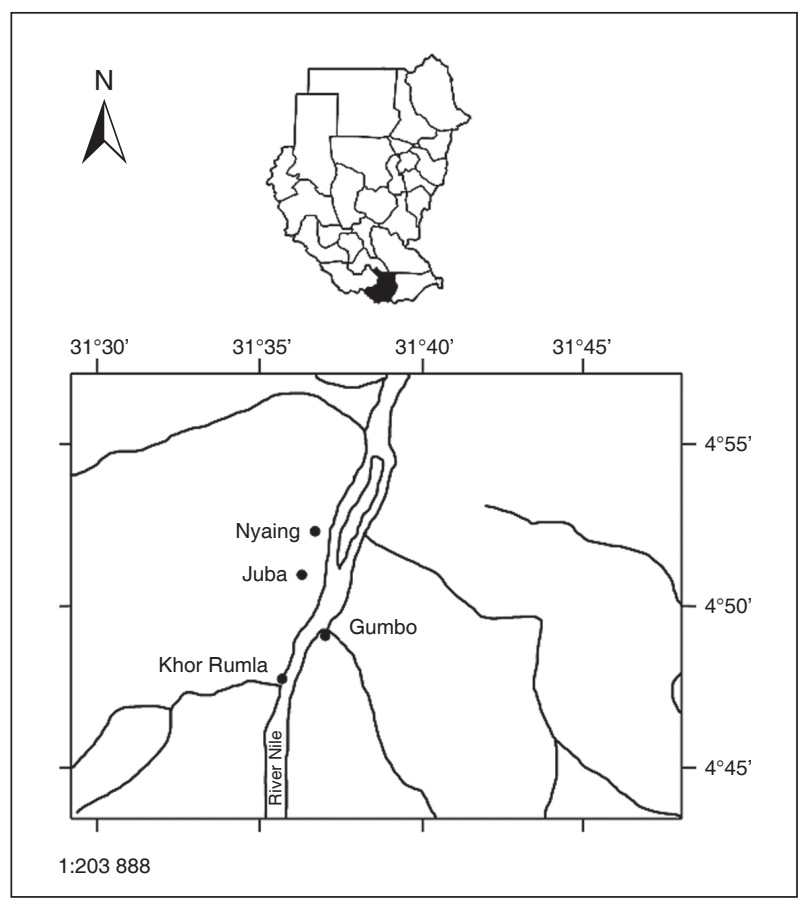

FIG. 1 Locations where samples were collected from Central Equatoria State, Southern Sudan. Top: map of the Sudan depicting its state boundaries. Black area: Central Equatoria State. Bottom: Juba area in Central Equatoria State depicting the locations where the samples were collected
March to November, with temperatures ranging between $19^{\circ}$ and $27^{\circ} \mathrm{C}$ and a rainfall between 800 and $1200 \mathrm{~mm}$.

\section{Collection of ticks}

A longitudinal survey, with a visit every 3 months, to three locations was conducted. The locations surveyed were Khor Rumla (15 km south of Juba), Nyaing (10 km north of Juba) and Gumbo (10 km south east of Juba) (Fig. 1). In each locality two cattle herds were regularly inspected at each visit. The visits were conducted in January (dry season), April (after the rain had commenced), July (peak of rainy season) and October (towards the end of the rainy season). From each herd, five animals (long-horned Nilotic Zebu cattle), three of them being calves (less than 1 year old) and two adult cattle (more than 4 years old) were sampled. At each visit the same herd was sampled, but not the same animals. A total body collection of ticks was made using a pair of blunt forceps. Prior to collection, each animal was cast and restrained. The ticks from each animal were collected separately and placed in labelled universal bottles containing $70 \%$ ethanol. On each label, location, animal identification number and date of collection were recorded. In the laboratory, the ticks were identified according to Hoogstraal (1956), Okello-Onen, Hassan \& Essuman (1999) and Walker, Bouattour, Camicas, Estrada-Peňa, Horak, Latif, Pegram \& Preston (2003).

\section{Statistical analysis}

The data on ticks were subjected to a general linear model (GLM) procedure using the Statistical Analysis System (SAS) package. SAS was used to perform analysis of variance (ANOVA) while mean separations were performed using the Ryan-EinotGabriel-Welsch (REGW) multiple range test (Day \& Quinn 1989). Correlation analysis was carried out to relate the means of the total body collections with monthly meteorological data.

\section{RESULTS}

A total of 2576 ticks was collected from 120 animals during the study period. Four genera and ten species of ticks were identified. The tick species identified were (in order of abundance): Amblyomma variegatum (38.2\%), Hyalomma marginatum rufipes (18.4\%), Hyalomma truncatum (15.3\%), Rhipicephalus appendiculatus (11.9\%), Rhipicephalus evertsi evertsi $(6.3 \%)$, Boophilus decoloratus (5.6\%), Rhipicephalus praetextatus (2.2\%), Boophilus annulatus 
TABLE 1 ANOVA mean squares (ME), R-squares (R), Coefficient of variance (CV) and F values (F) for total body collections of ticks from cattle in Central Equatoria State, Southern Sudan during the year 2005

\begin{tabular}{|c|c|c|c|c|}
\hline Source of variation & ME & $\mathbf{R}$ & CV & $\mathbf{F}$ \\
\hline A. variegatum & 117.30 & 0.17 & 75.58 & $2.12^{*}$ \\
\hline B. annulatus $\$$ & 1.75 & 0.20 & 214.5 & $2.63^{* * *}$ \\
\hline B. decoloratus & 35.57 & 0.52 & 128.18 & $10.59^{\star * *}$ \\
\hline H. m. rufipes & 665.02 & 0.81 & 81.17 & $41.53^{\star \star \star}$ \\
\hline H. truncatum & 574.20 & 0.73 & 117.45 & $26.68^{\star \star *}$ \\
\hline R. appendiculatus & 23.20 & 0.24 & 87.73 & $3.16^{* * *}$ \\
\hline R. e. evertsi & 31.07 & 0.51 & 106.90 & $10.36^{\star * *}$ \\
\hline R. praetextatus & 1.17 & 0.16 & 141.04 & $1.87^{\mathrm{NS}}$ \\
\hline Total & 3555.9 & 0.75 & 42.0 & $30.30^{\star \star \star}$ \\
\hline
\end{tabular}

$\$ \quad$ Females only

NS Not significant

Degrees of freedom $=9$

* $\quad P \leq 0.05,{ }^{* * *}=P \leq 0.001$

TABLE 2 Means $( \pm$ SE) of total body collection of ticks from cattle at different locations in Central Equatoria State, Southern Sudan during the year $2005^{*}$

\begin{tabular}{|c|c|c|c|}
\hline \multirow{2}{*}{ Tick species } & \multicolumn{3}{|l|}{ Locations } \\
\hline & Gumbo & Nyaing & Khor Rumla \\
\hline A. variegatum & $10.9 \pm 1.3^{a}$ & $9.6 \pm 1.5^{a}$ & $9.0 \pm 1.2^{\mathrm{a}}$ \\
\hline B. annulatus $\$$ & $0.2 \pm 0.06^{b}$ & $1.0 \pm 0.6^{a}$ & $0.3 \pm 0.08^{b}$ \\
\hline B. decoloratus & $0.8 \pm 0.2^{b}$ & $3.8 \pm 1.0^{\mathrm{a}}$ & $0.9 \pm 0.2^{b}$ \\
\hline H. m. rufipes & $6.0 \pm 1.6^{a}$ & $1.0 \pm 0.2^{b}$ & $5.9 \pm 1.4^{a}$ \\
\hline H. truncatum & $5.8 \pm 1.7^{a}$ & $0.0 \pm 0.0^{b}$ & $4.1 \pm 1.2^{\mathrm{a}}$ \\
\hline R. appendiculatus & $3.0 \pm 0.5^{a}$ & $2.7 \pm 0.6^{a}$ & $3.4 \pm 0.5^{\mathrm{a}}$ \\
\hline R. e. evertsi & $1.1 \pm 0.3^{b}$ & $0.9 \pm 0.3^{b}$ & $2.5 \pm 0.5^{\mathrm{a}}$ \\
\hline R. praetextatus & $0.6 \pm 0.1^{b}$ & $1.0 \pm 0.2^{a}$ & $0.4 \pm 0.1^{b}$ \\
\hline Total & $28.2 \pm 4.2^{\mathrm{a}}$ & $19.9 \pm 2.0^{b}$ & $26.4 \pm 2.8^{a}$ \\
\hline
\end{tabular}

$\$ \quad$ Females only

Number of observations $=40$ in each location

Means ( \pm SE) followed by the same letter in each column are not significantly different at $5 \%$ level based on Ryan's $Q$ test (REGWQ)

* Collection was carried out four times in each location

TABLE 3 Means $( \pm$ SE) of total body collection of ticks from cattle in different months in Central Equatoria State, Southern Sudan during the year 2005*

\begin{tabular}{|c|c|c|c|c|}
\hline \multirow[t]{2}{*}{ Tick species } & \multicolumn{4}{|l|}{ Months } \\
\hline & January & April & July & October \\
\hline A. variegatum & $6.7 \pm 0.8^{a}$ & $11.7 \pm 1.4^{\mathrm{a}}$ & $12.0 \pm 2.1^{\mathrm{a}}$ & $9.8 \pm 2.1^{a}$ \\
\hline B. annulatus $\$$ & $0.2 \pm 0.07^{b}$ & $0.8 \pm 0.3^{a}$ & $0.0 \pm 0.0^{b}$ & $0.5 \pm 0.1^{a}$ \\
\hline B. decoloratus & $0.4 \pm 0.1^{b}$ & $3.5 \pm 0.7^{a}$ & $0.1 \pm 0.07^{b}$ & $1.2 \pm 0.2^{b}$ \\
\hline H. m. rufipes & $0.7 \pm 0.1^{b}$ & $0.8 \pm 0.2^{\mathrm{b}}$ & $2.2 \pm 0.5^{b}$ & $20.3 \pm 1.9^{a}$ \\
\hline H. truncatum & $0.2 \pm 0.1^{b}$ & $0.4 \pm 0.1^{\mathrm{b}}$ & $0.7 \pm 0.2^{b}$ & $18.2 \pm 2.3^{a}$ \\
\hline R. appendiculatus & $3.0 \pm 0.5^{b}$ & $2.5 \pm 0.5^{b}$ & $1.6 \pm 0.2^{b}$ & $5.7 \pm 0.8^{a}$ \\
\hline R. e. evertsi & $1.4 \pm 0.3^{b}$ & $0.2 \pm 0.1^{c}$ & $1.1 \pm 0.2^{b, c}$ & $4.6 \pm 0.8^{a}$ \\
\hline R. praetextatus & $0.5 \pm 0.1^{\mathrm{a}}$ & $0.7 \pm 0.2^{\mathrm{a}}$ & $0.3 \pm 0.1^{\mathrm{a}}$ & $0.7 \pm 0.2^{\mathrm{a}}$ \\
\hline Total & $13.1 \pm 0.9^{c}$ & $20.6 \pm 1.6^{b}$ & $17.9 \pm 2.2^{b, c}$ & $60.7 \pm 4.2^{\mathrm{a}}$ \\
\hline
\end{tabular}

\section{$\$ \quad$ Females only}

Number of observations $=30$ in each month

Means ( \pm SE) followed by the same letter in each column are not significantly different at $5 \%$ level based on Ryan's Q test (REGWQ)

* Collection was carried out from five animals in six herds in each month 
Ticks (Acari: Ixodidae) on cattle in Southern Sudan

TABLE 4 Correlation analysis between means of total body tick collection and climatic factors in Central Equatoria State, Southern Sudan during the year 2005

\begin{tabular}{|c|c|c|c|c|}
\hline \multirow{2}{*}{ Tick species } & \multicolumn{4}{|c|}{ Climatic factors } \\
\hline & Max & Min & RH & Rain \\
\hline \multirow[t]{3}{*}{$\begin{array}{l}\text { A. variegatum } \\
\text { B. annulatus } \$ \\
\text { B. decoloratus } \\
\text { H. m. rufipes } \\
\text { H. truncatum } \\
\text { R. appendiculatus } \\
\text { R. e. evertsi } \\
\text { R. praetextatus }\end{array}$} & $\begin{array}{l}0.078 \\
0.235^{\star \star} \\
0.381^{\star \star *} \\
-0.352^{\star \star *} \\
-0.292^{\star \star *} \\
-0.008 \\
-0.288^{\star * *} \\
0.136\end{array}$ & $\begin{array}{l}0.210^{*} \\
0.289^{\star * *} \\
0.543^{\star * *} \\
-0.109 \\
-0.093 \\
-0.068 \\
-0.278^{\star *} \\
0.105\end{array}$ & $\begin{array}{l}0.213^{\star} \\
-0.065 \\
-0.071 \\
0.391^{\star \star \star} \\
0.333^{\star \star \star} \\
0.008 \\
0.193^{\star} \\
-0.074\end{array}$ & $\begin{array}{c}0.261^{\star \star *} \\
-0.018 \\
0.061 \\
0.083 \\
0.040 \\
0.148 \\
-0.069 \\
0.070\end{array}$ \\
\hline & \multicolumn{4}{|c|}{ Climatic factors (previous month) } \\
\hline & Max & Min & RH & Rain \\
\hline $\begin{array}{l}\text { A. variegatum } \\
\text { B. annulatus } \$ \\
\text { B. decoloratus } \\
\text { H. m. rufipes } \\
\text { H. truncatum } \\
\text { R. appendiculatus } \\
\text { R. e. evertsi } \\
\text { R. praetextatus }\end{array}$ & $\begin{array}{l}0.001 \\
0.255^{\star} \\
0.457^{\star * *} \\
-0.465^{\star * *} \\
-0.408^{\star * *} \\
-0.106 \\
-0.416^{\star * *} \\
0.124\end{array}$ & $\begin{array}{l}0.233^{\star} \\
0.246^{\star} \\
0.501^{\star * *} \\
-0.231^{\star} \\
-0.219^{\star} \\
-0.160 \\
-0.364^{\star * *} \\
0.071\end{array}$ & 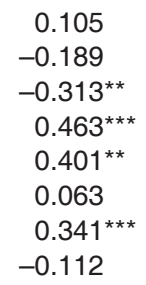 & $\begin{array}{c}0.177 \\
-0.153 \\
-0.202 \\
0.250^{\star} \\
0.192^{*} \\
0.072 \\
0.138 \\
-0.119\end{array}$ \\
\hline
\end{tabular}

$\$ \quad$ Females only

${ }^{*} \quad=P \leq 0.05,{ }^{* *}=P \leq 0.01,{ }^{* * *}=P \leq 0.001$

Max $=$ Mean maximum temperature

Min = Mean minimum temperature

$\mathrm{RH}=$ Relative humidity

Rain = Rainfall

TABLE 5 Means $( \pm S E)$ of total body collection of ratio of males to females $(M / F)$ in Central Equatoria State, Southern Sudan during the year 2005

\begin{tabular}{|l|l|l|l|l|l|l|l|}
\hline Ratio & \multicolumn{2}{|l|}{ Location } & \multicolumn{2}{l|}{ Season } \\
\hline \multirow{2}{*}{ M/F } & Gumbo & Nyaing & K. Rumla & January & April & July & October \\
\cline { 2 - 8 } & $2.8 / 1 \pm 0.4^{\mathrm{a}}$ & $3.0 / 1 \pm 0.7^{\mathrm{a}}$ & $2.1 / 1 \pm 0.4^{\mathrm{a}}$ & $4.0 / 1 \pm 0.7^{\mathrm{a}}$ & $2.6 / 1 \pm 0.4^{\mathrm{a}, \mathrm{b}}$ & $2.1 / 1 \pm 0.6^{\mathrm{b}}$ & $1.0 / 1 \pm 0.1^{\mathrm{b}}$ \\
\hline
\end{tabular}

Means $( \pm \mathrm{SE}$ ) followed by the same letter in each row are not significantly different at $5 \%$ level based on Ryan's Q test (REGWQ)

(1.5\%), Amblyomma lepidum (0.4\%) and Rhipicephalus sanguineus group ( $0.2 \%)$. Male ticks usually outnumbered females except for Boophilus spp.

ANOVA, mean squares, R-squares, Coefficient of Variance and $F$ values are shown in Table 1. The mean tick load per animal was found to be lowest in January (16.2) and the highest in October (53.8). As far as locations are concerned, at Nyaing the lowest tick infestation was found $(19.9 \pm 2.0)$, which was significantly different $(P<0.05)$ from the other two locations (Gumbo, 28.2 \pm 4.2 and Khor Rumla 26.4 \pm 2.8 ) (Table 2). With respect to the season of collection, it was found that tick infestation increased significantly $(P<0.05)$ from $13.1 \pm 0.9$ in January (dry season) to $60.7 \pm 4.2$ in October (towards the end of the rainy season) (Table 3). Male hosts were found to carry more ticks $(29.9 \pm 3.3)$ than female hosts $(22.3 \pm 2.6)$. Significant differences $(P<0.05)$ were observed in the male/female tick ratio in the October collection (Table 5). Data on distribution, abundance, seasonality and correlation between mean tick count and climatic factors are presented separately below for each species.

\section{Amblyomma lepidum Dönitz, 1909}

Only four males and six females of the East African bont tick were collected during this study. Three males were collected from Gumbo in April, whereas the fourth one was collected from Khor Rumla in October, associated with two females, while the other four females were collected from the same location in the same season, but without males. This 
tick species represent only $0.4 \%(10 / 2576)$ of all ticks collected. Due to the very small number, this species was not included in the statistical analysis.

\section{Amblyomma variegatum Fabricius, 1794}

The tropical bont tick was the most predominant tick species, representing $38.2 \%$ (984/2576) of the total number of ticks collected. There was no significant difference in the mean collection among the three locations surveyed, ranging from $9.0 \pm 1.2$ in Khor Rumla to $10.9 \pm 1.3$ in Gumbo (Table 2). The highest mean (12.0 \pm 2.1$)$ was recorded in the middle of the rainy season (Table 3 ). Female hosts were found to carry more of this species than male hosts. A positive correlation $(r=0.261, P \leq 0.001)$ was found between rainfall and the mean body collection (Table $4)$.

\section{Boophilus annulatus Say, 1821}

Only one $B$. annulatus male was collected in January in Khor Rumla, therefore only females of this species were subjected to statistical analysis. The mean total body collection of this tick species in Nyaing $(1.0 \pm 0.6)$ was found to be significantly higher $(P<$ $0.05)$ compared with other locations (Table 2). No ticks of this species were collected during July, whereas the highest mean $(0.8 \pm 0.3)$ was collected during April (Table 3). Female abundance was found to be positively correlated with ambient temperatures (maximum and minimum) and negatively correlated with rainfall and relative humidity $(r=-0.018$, $P>0.05$ and $r=-0.065, P>0.05$, respectively) (Table 4).

\section{Boophilus decoloratus Koch, 1844}

The blue tick was found together with $B$. annulatus in Nyaing with the highest mean total per animal (3.8 \pm 1.0$)$, which was significantly higher $(P<0.05)$ as compared with the other locations (Table 2). This

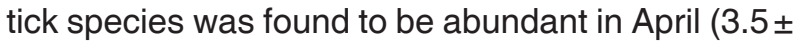
$0.7)$ which was significantly different $(P<0.05)$ compared with other seasons (Table 3 ). The correlation analysis indicated that this tick species is also affected by climatic factors as for $B$. annulatus, with the exception of rainfall, which was positively but not significantly correlated $(r=0.061)$ (Table 4).

\section{Hyalomma marginatum rufipes Koch, 1844}

The highest mean number of the hairy Hyalomma was collected from Gumbo $(6.0 \pm 1.6)$, but was not significantly different $(P>0.05)$ from the infestation at Khor Rumla, while the infestation in these two locations were significantly higher $(P<0.05)$ compared with the infestation at Nyaing (Table 2). This tick was most abundant during the rainy season (October) when the highest mean infestation per animal was recorded $(20.3 \pm 1.9)$ (Table 3$)$. A significant negative correlation was found with mean maximum temperature $(r=-0.352, P<0.001)$ and mean minimum temperature $(r=-0.109, P>0.05)$ (Table 4$)$.

\section{Hyalomma truncatum Koch, 1844}

The African Hyalomma was not found at Nyaing, whereas the mean tick burdens at the other two locations were not significantly different $(P>0.05)$ (Table 2). This tick species was found to be abundant during October with mean number of $18.2 \pm 2.3$ (Table 3). The effect of climatic factors on this species was found to be the same as for Hyalomma m. rufipes (Table 4).

\section{Rhipicephalus appendiculatus Neumann, 1901}

The brown ear tick was recorded in all locations and seasons with the collection in October $(5.7 \pm 0.8)$ being significantly larger $(P<0.05)$ compared with other collections (Table 3 ). The presence of this tick was found to be negatively but not significantly correlated with mean temperature (maximum, $r=-0.008$, minimum, $r=-0.068$ ) and positively but not significantly correlated with relative humidity $(r=0.008)$ and rainfall $(r=0.148)$ (Table 4).

\section{Rhipicephalus evertsi evertsi Neumann, 1897}

The mean infestation of the red legged tick in Khor Rumla was $2.5 \pm 0.5$ which was significantly higher $(P<0.05)$ than in the other locations (Table 2). The infestation in October was the highest $(4.6 \pm 0.8)$ and significantly different $(P<0.05)$ from the other seasons (Table 3 ). There was a significant positive correlation of the mean numbers of this tick species with relative humidity $r=0.193(P<0.05)$ (Table 4).

\section{Rhipicephalus praetextatus Gerstäcker, 1873}

This tick species was recorded at Nyaing $(1.0 \pm 0.2)$ with the highest mean infestation and was significantly different $(P<0.05)$ from the other locations (Table 2). The infestation with this tick was not significantly different between different seasons $(P>0.05)$ (Table $3)$. A negative correlation $(r=-0.074)$ was found with relative humidity (Table 4 ).

\section{Rhipicephalus sanguineus group Latreille, 1806}

Only six ticks belonging to the Rhipicephalus sanguineus group were collected during the period of 
study. Two females were collected from Gumbo in January, while four males were collected from Nyaing in the same month. This tick was not included in the statistical analysis.

\section{DISCUSSION}

Since the previous surveys on ticks in the Southern Sudan (Hoogstraal 1956; Anonymous 1983; Jongejan, Zivkovic, Pegram, Tatchell, Fison, Latif \& Paine 1987; Julla 1994), no work has been carried out on ticks in Southern Sudan due to civil unrest. In the present study, four genera and ten species of ticks were identified (Table 1), compared to eight genera and 46 species and subspecies of ticks identified by Hoogstraal (1956), five genera and eight species by Anonymous (1983) and five genera and 12 species by Julla (1994). These differences may be attributed to the fact that the present survey was limited to cattle around Juba town only, whereas Hoogstraal (1956) included ticks from all livestock and wildlife in Equatoria region, as did Julla in his survey conducted in 1994.

The mean number of ticks per head of cattle in Central Equatoria State was relatively low throughout the study period with the exception of the October collection (Table 3 ). This may be attributed to the fact that indigenous cattle are generally highly successful in developing resistance to ticks (Latif 1984). Males constituted the majority of all species with the exception of Boophilus spp., which males are difficult to find on the host (Tatchell \& Easton 1986). The highest collection of ticks combined with an equal male/female ratio obtained during October (Tables 3 and 5), indicates that the rainy season is favorable for the breeding of ticks in Central Equatoria State.

The small number of $A$. lepidum ticks (ten specimens) found in this survey confirms its patchy distribution (Osman \& Hassan 2003). Hoogstraal (1956) and also Anonymous (1983), for instance, did not find this tick species in Central Equatorial State but Julla (1994) did, which may indicate the continuous shifting of its microhabitat. The distribution limits of ticks are not fixed and constant. They are determined by a complicated interplay of factors such as climate, vegetation, host density, host resistance and animal husbandry practices (Tatchell \& Easton 1986). More important is the finding that this tick species is spreading south (W. Lako, unpublished data 2006).

Rhipicephalus appendiculatus is the most important rhipicephalid tick in East and Southern Africa where it infests a wide variety of domestic and wild ruminants (Jongejan \& Uilenberg 2004). The year-round presence of $R$. appendiculatus (Table 3 ), confirms that it has firmly established itself in Central Equatoria State. This finding provides an answer to the query by Jongejan et al. (1987) as to "whether this tick is repeatedly introduced by seasonal migration of livestock or is able to maintain itself around Juba?" and confirms the previous finding of Julla (1994). Moreover, the latter author indicated that East Coast fever and its vector $R$. appendiculatus has not only become established in Juba but has also extended to Terekaka area ( $60 \mathrm{~km}$ north of Juba).

The distribution and abundance of $R$. appendiculatus are key determinants in the epidemiology of East Coast fever (Lessard, L'eplattenier, Norval, Kundert, Dolan, Croze, Walker, Irvin \& Perry 1990). This distribution can be influenced by the climate as well as many other factors such as the presence, abundance, movement of cattle, the resistance of the host to ticks and tick-borne diseases and the vegetation cover. In this study, there was a pronounced effect of climatic factors on the numbers of $R$. appendiculatus ticks as well as many other tick species (Table 4). The presence of $R$. appendiculatus was found to be negatively correlated with mean maximum temperature $(r=-0.008)$ as well as mean minimum temperature $(r=-0.068)$. This finding is in accord with suggestions of Tatchell \& Easton (1986), who reported that the life cycle of this tick species is very precisely controlled by the combined effect of low temperatures, slowing developmental rates and lack of rain in the dry season preventing early resumption of feeding by adults produced from the first fed nymphs.

The most abundant tick species in Juba area was $A$. variegatum (38.2\%) compared with $R$. appendiculatus $(11.9 \%)$. It is known that $A$. variegatum has a broader distribution than $R$. appendiculatus, being able to survive in hotter drier environments (Tatchell \& Easton 1986). In those African countries which have one rainy season per year, $A$. variegatum and $R$. appendiculatus usually have one generation per year (Dipeolu 1989). This fact is clearly evident from the results of the present investigation, i.e. that there is only one generation of $R$. appendiculatus per year in Southern Sudan.

As far as tick control is concerned, acaricides are only applied when tick numbers are very high. The type of strategic tick control to be implemented in a certain area requires a sound knowledge of vector ecology and disease epidemiology. Moreover, the nature of the farming system and socio-economic 
considerations will also have an important influence in the success of this approach (De Castro 1997). Here, it is concluded that indigenous Zebu cattle are successful in developing resistance to ticks in Central Equatoria State, as inferred from the low tick burdens detected in the present study. It remains to be shown whether the current situation is the best one possible with respect to keeping losses due to ticks and tick-borne diseases low without much use of acaricides. However, a cross-sectional and longitudinal survey in the same region would be required to answer the fore-going questions.

\section{ACKNOWLEDGEMENTS}

This research was supported by the International Foundation for Science, Stockholm, Sweden and the Organisation of Islamic Conference Standing Committee on Scientific and Technological Cooperation (COMSTECH), Islamabad, Pakistan through a grant to Mr Diaeldin Ahmed Salih (IFS grant 3765-1). This work is published by kind permission of the DirectorGeneral of Research, Ministry of Animal Resources and Fisheries, Government of South Sudan and the Director-General, Animal Resources Research Corporation, Khartoum.

\section{REFERENCES}

ANONYMOUS 1983. Tick and tick-borne disease control, the Sudan. Tick ecology and tick control. AG: GCP/SUD/024/DEN. Technical Report 1. Rome: Food and Agricultural Organization.

DAY, R.W. \& QUINN, G.P. 1989. Comparison of treatment after an analysis of variance in ecology. Ecological Monographs, 59:433-463.

DE CASTRO, J.J. 1997. Sustainable tick and tick-borne disease control in livestock improvement in developing countries. Veterinary Parasitology, 71:77-97.

DIPEOLU, O.O. 1989. Research on ticks of livestock in Africa: Review of the trends, advances and milestones in tick biology and ecology in the decade 1980-1989. Insect Science and its Application, 10:723-740.
HOOGSTRAAL, H. 1956. African Ixodoidea. I. Ticks of the Sudan (with special reference to Equatoria Province and with preliminary reviews of the genera Boophilus, Margaropus and Hyalomma). Department of the Navy, Bureau of Medicine and Surgery, Washington, D.C., USA.

JONGEJAN, F., ZIVKOVIC, D., PEGRAM, R.G., TATCHELL, R.J., FISON, T., LATIF, A.A. \& PAINE, G. 1987. Ticks (Acari: Ixodidae) of the Blue and White Nile ecosystems in the Sudan with particular reference to the Rhipicephalus sanguineus group. Experimental and Applied Acarology, 3:331-346.

JONGEJAN, F. \& UILENBERG, G. 2004. The global importance of ticks. Parasitology, 129:S1-S12.

JULLA, I.I. 1985. Theileriosis in the South Sudan, in Immunization against theileriosis in Africa, edited by A.D. Irvin. Proceedings of a workshop held at ILRAD, Nairobi, Kenya, 1-5 October 1984: 27-30.

JULLA, I.I. 1994. Studies on the epidemiology of theileriosis in Equatorial Region of the Sudan with emphasis on East Coast fever. Ph.D. thesis, University of Khartoum.

LATIF, A.A. 1984. Resistance to Hyalomma anatolicum anatolicum Koch (1844) and Rhipicephalus evertsi Neumann (1897) (Ixodoidea: Ixodidae) by cattle in the Sudan. Insect Science and its Application, 5:509-511.

LESSARD, P., L'EPLATTENIER, R., NORVAL, R.A.I., KUNDERT, K., DOLAN, T.T., CROZE, H., WALKER, J.B., IRVIN, A.D. \& PERRY, B.D. 1990. Geographical information systems for studying the epidemiology of cattle diseases caused by Theileria parva. Veterinary Record, 17:255-262.

MORZARIA, S.P., TATCHELL, R.J., MINOR, R., PEDERSON, V., JULLA, I., RAHIM, A., DYSON, D. \& AARLE, P.A.M. 1981. Preliminary studies on the epidemiology of theileriosis in Eastern Equatoria Province of the Sudan, in Advances in the control of theileriosis, edited by A.D. Irvin, M.P. Cunningham \& A.S. Young. The Hague: Martinus Njihoff Publishers.

OKELLO-ONEN, J., HASSAN, S.M. \& ESSUMAN, S. 1999. Taxonomy of African ticks: An identification manual. Nairobi: ICIPE Science Press.

OSMAN, A.M. \& HASSAN, S.M. 2003. The ecology and distribution of the East Africa tick Amblyomma lepidum: A review. The Sudan Journal of Veterinary Science \& Animal Husbandry, 42(1 \& 2):45-53.

TATCHELL, R.J. \& EASTON, E. 1986. Tick (Acari: Ixodidae) ecological studies in Tanzania. Bulletin of Entomological Research, 76:229-246.

WALKER, A.R., BOUATTOUR, A., CAMICAS, J.L., ESTRADAPEŇA, A., HORAK, I.G., LATIF, A.A., PEGRAM, R.G. \& PRESTON, P.M. 2003. Ticks of domestic animals in Africa: A guide to identification of species. Edinburgh, Scotland: Bioscience Reports. 